\title{
“JOKI KECIL": FAKTA DAN FIKSI DALAM SUDUT PANDANG KOGNITIF
}

\author{
Renta Vulkanita Hasan dan A. Lilik Slamet Raharsono \\ FIB Universitas Negeri Jember \\ e-mail: rentavulkanita.sastra@unej.ac.id
}

\begin{abstract}
Abstrak
"Joki Kecil" (Yuli Andari, 2005) peneliti anggap sebagai film dokumenter yang menarik untuk dikaji dalam konteks disposisi kebenaran dokumenter.Kebenaran menjadi istilah yang peneliti pilih karena menurut peneliti, sampai saat ini masih terdapat problem yang mempermasalahkan sisi "kebenaran" pada dokumenter.Dalam tinjauan awal ini, peneliti memposisikan diri sebagai penonton, baik secara aktual (bertindak sebagai konsumen film pada umumnya, duduk dan menikmati setiap jalan cerita yang disajikan) dan secara kontekstual (bertindak sebagai seseorang yang sedang mencari kebenaran dalam sebuah dokumenter dengan bekal pertanyaan teoretis pada wilayah kajian dokumenter), melalui pengalaman faktual dan imajinasi saat menonton dokumenter itu.Persamaan dan perbedaan menjadi dua kelompok penting dalam mengungkap kebenaran dalam dokumenter yang ditonton. Melalui persamaan dan perbedaan, penonton akan menggunakan struktur mental untuk menjelaskan mengapa proses mental dan pemahaman seseorangtentang duniamemiliki stabilitas dan keteraturan seperti yang orang lain lakukan dan mengapa dunia fenomenaldalam banyak kasus nampak terlihat berbeda dari "dunia nyata."
\end{abstract}

Kata kunci: dokumenter, fakta, fiksi, kognitif

\section{"JOKI KECIL": FACTS AND FICTION IN COGNITIVE VIEW “}

\begin{abstract}
The researcher considers "Joki Kecil" (Yuli Andari, 2005) as an interesting documentary to discuss in the context of truth disposition. Truth is the right term chosen because there are still problems related to it when talking about documentary. In this early study, the researcher acts as a spectator, whether as a real one, sitting and enjoying the story performed, or contextual one, trying to find out the truth in thiskind of film by having theoreticalquestions in terms of documentary study, through factual experience and imagination. These similarities as well as differences become two important parts in trying to find out the truth in the documentary being watched. Through these, the audience will use mental structure to be able to explain why somebody's mental and understanding processes have stability and regularity, and why world's phenomena in many cases seem to be different from the real world.
\end{abstract}

Keywords: documentary, facts, fiction, cognitive 


\section{A. PENDAHULUAN}

Mengupas suatu isu kebenaran dalam dokumenter bukan semata-mata mengungkap pembuktian melalui gambar dalam film yang telah merekam realitas berdasarkan topik yang ditekankan oleh si pembuat film melalui peran aktor sosial. Lebih jauh, kebenaran dalam dokumenter tidak hanya dilihat dari sisi kebenaran filmis, tetapi juga dilihat dari sisi yang memungkinkan argumentasi lain, yaitukebenaran dokumenter yang tidak selalu faktual dan mengandung unsur fiksi. ${ }^{1}$ Argumentasi lain tersebut merupakan peluang bagi peneliti untuk menawarkan proses tentangcara melihat kebenaran dokumenter secara objektif.Bagi peneliti, objektivitas merupakan posisi yang menjadikan dokumenter dapat dipandang sebagai objek yang memiliki relasi antara fakta dan fiksi dalam menyampaikan kebenaran melalui proses (1) pelegitimasian dan (2) pemaknaan. ${ }^{2} \mathrm{Hal}$ inilah yang menjadi pertimbangan peneliti bahwa kebenaran sesungguhnya berhubungan erat dengan objektivitas. Bagi peneliti, argumentasi tentang hubungan antara dokumenter dan kebenaran merupakan masalah yang belum dapat diselesaikan melalui beberapa jalurseperti: aktualitas dan subjektivitas. ${ }^{3}$ Peneliti berpendapat bahwa untuk membuktikan objektivitas yang

\footnotetext{
${ }^{1}$ Kebenaran filmis merupakan kebenaran yang melekat pada aspek-aspek sinematografi, di mana aspek tersebut bergantung pada kombinasi shot yang dirangkai melalui montase (proses atau teknik memilih, mengedit, dan menyatukan bagian-bagian yang terpisah dari film untuk membentuk keseluruhan yang kontinyu) dengan pertimbangan tempo, kecenderungan pada frame, dan kelanjutan tiap shot (Eisenstein, 1969: 64)

${ }^{2}$ Cara objektivitas bekerja dengan mengamati relasi antara aktualitas dan subjektivitas dalam menunjukkan kebenaran ini merujuk pada pendapat Blumenberg yang mengatakan bahwa mustahil untuk mencapai unsur keaslian dalam film, menurut Blumenberg, keaslian mungkin diinginkan sebagai kriteria penting untuk film-film yang dimaksudkan untuk menunjukkan "kebenaran." Blumenberg menawarkan bahwa keaslian dapat dicapai melalui dua kualitas yang diperoleh melalui pemberian (1) legitimasi dan (2) makna (Blumenberg, 1977: 19).

${ }^{3}$ Bill Nichols menyebutkan bahwa realisme dokumenter terletak pada bagaimana visi dan gaya sineas dokumenter memunculkan irama dan dunia imajiner melalui pertanyaan tentang bagaimana sudut pandang personal seputar dunia sejarah memanifestasikan dirinya (Nichols, 1991: 165). Dalam hal ini peneliti menganggap bahwa Nichols berusaha mengupas permasalahan realitas dalam dokumenter melalui jalur subjektivitas yang menekankan otoritas dari si pembuat film. Pada sisi lain, Linda Williams menyebutkan bahwa dikotomi yang terlalu sederhana antara kebenaran dan fiktif merupakan akar dari kesulitan kita dalam berpikir tentang kebenaran dalam film dokumenter.
} 
memuat tentang hubungan antara dokumenter dan kebenaran, dibutuhkan peran kognitif yang meletakkan hubungan antara dokumenter dankebenaran pada cara pandang disposisi yang melibatkan struktur mental. ${ }^{4}$ Untuk mengungkap kasus kebenaran dokumenter yang berhubungan erat dengan objektivitas, peletakan sudut pandang kognitif perlu digunakan untuk melihat sejauh mana penonton mampu menangkap rangkaian gambar dan mengingat tiap potongannya melalui penafsiran pengalaman inderawi secara aktif, yaitu: mencipta, mengorganisasikan, menafsirkan, mendistorsi, dan mencari makna (Persson, 2003). Penafsiran pengalaman inderawi disebut sebagai suatu disposisi kebenaran yang memperlihatkan adanya unsur fakta dan fiksi dalam dokumenter yang merujuk pada proses kognitif. Disposisi merupakan istilah dalam sudut pandang kognitif yang peneliti anggap tepat untuk melihat relasi antara dokumenter dan kebenaran melalui cara penonton dalam melibatkan struktur mental untuk menyadari keberadaan faksi. Faksi merupakan hasil dari proses struktur mental penonton dalam memahami hubungan kebenaran dengan gambar dalam dokumenter. Faksi bukanlah istilah baru dalam dokumenter, karena sebelumnya telah digunakan oleh Keith Beattie melalui perspektif behavior untuk mengupas problem selera penonton terhadap dokumenter (Beattie, 2004). Sebelum Beattie, istilah faksi juga digunakan oleh Blumenberg dalam menjembatani kesenjangan terhadap

Pilihannya adalah bukan berada di antara dua rezim yang sama sekali terpisah dari kebenaran dan fiktif. Pilihan itu, agaknya, merupakan strategi fiktif untuk pendekatan kebenaran relatif. Menurut Williams, Dokumenter memang bukan fiktif dan tidak boleh digabungkan dengan itu, namun dokumenter dapat dan harus menggunakan semua strategi pembangunan fiktif untuk mendapatkan kebenaran (Williams, 1993, 20). Linda Williams, dalam hal ini peneliti anggap telah berusaha mengupas problem kebenaran melalui jalur aktualitas dengan penekanan pada bentuk film. Gagasan Nichols dan Williams, juga peneliti anggap sejalan dengan Jerry Kuehl yang menyatakan bahwa salah satu strategi alternatif sineas dalam menghadirkan kebenaran dalam suatu film adalah menciptakan film yang melahirkan klaim kebenaran tanpa harus mengucapkan cerita-cerita, yang dalam hal ini menggunakan komentar, gambar, dan pernyataan langsung dari partisipan tanpa mempekerjakan aktor (Kuehl, 1988: 103). Kuehl menganggap bahwa genre dokumenter-drama adalah bentuk ciptaan dari strategi tersebut.

${ }^{4}$ Struktur mental dapat dilihat sebagai pola atau mediator yang mengubah, meningkatkan, memperkaya, dan menggeneralisasi rangsangan yang masuk untuk menghasilkan dunia fenomenal (Persson, 2003: 8). 
pemahaman tentang identifikasi unsur keaslian terhadap konstruksi fiksional (Blumenberg, 1977: 21).

"Joki Kecil" merupakan film dokumenter bergaya ekspositori dengan meletakkan ciri khas penggunaan narasi melalui pola wawancaraterhadap aktor sosial yang digunakan. ${ }^{5}$ Joki kecil bercerita tentang tradisi pacuan kuda di wilayah Sumbawa yang dianggap sebagai tradisi yang turun-temurun.Dalam film itu nampak tergambar suatu kepercayaan masyarakat terhadap hal-hal magis. Gambaran tersebut terdapat pada beberapa shot yang memperlihatkan adegan saat pertunjukan pacuan kuda dilaksanakan, terlihat seseorang yang disebut dengan "dukun" (orang sakti) sedang melakukan suatu ritual. Kehadiran anak-anak kecil yang berprofesi sebagai Joki, lingkungan tradisi di sekitar anak-anak penjoki, dan perlakuan terhadap anak-anak penjoki menjadi point of interest bagi peneliti saat mereka direkam.Dokumenter "Joki Kecil'berisi rangkaian gambar dan narasi berbentuk wawancara dengan, baik itu dengan si pemilik kuda maupun anak-anak penjoki itu sendiri.Melalui narasi tersebut, seorang anak laki-laki bercerita tentang pengalaman ketika menjoki kuda, seperti terjatuh, menabrak besi pembatas pacuan, dan bibir berdarah akibat menabrak papan.Beberapa insiden tergambar melalui film saat adegan pertunjukan pacuan kuda berlangsung, seperti: joki yang menangis dan meronta saat dipaksa menjoki kuda.

\section{B. PEMBAhaSAN}

Pengamatan peneliti ditujukanpada unsur fakta dan fiksi yang dilihat melaluirangkaiangambar dan suara dalam film dokumenter "Joki Kecil”. Unsur fakta dan fiksi yang terdapat dalam dokumenter merupakan pertimbanganbagi peneliti untuk membandingkan kesesuaian antara narasi dengan gambar. Menurut peneliti, ada rangkaian narasi yang dimunculkan melalui adegan wawancara yang tidak

${ }^{5}$ Dokumenter ekspositori merupakan salah satu gaya dalam dokumenter yang menyertakan narasimelalui penyatuannya dengan serangkaian gambar dengan tujuan agar lebih deksriptif dan informatif. Narasi dalam hal ini berusaha menawarkan serangkaian fakta dan argumentasi melalui ilustrasi dalam shot-shot yang disisipkan dalam narasi tersebut. Narasi dapat berbentuk voice over maupun wawancara. Dokumenter ekspositori merupakan salah satu dari 6 gaya dokumenter yang dirumuskan oleh Bill Nichols (Nichols, 2001: 22). 
menggambarkan situasi yang sama dengan kondisi saat subjek bercerita. Peneliti menganggap bahwa narasi tersebut seolah mengungkapkan legitimasi atas peristiwa tertentu yang belum terbukti kebenarannyamelalui gambar yang terekam di sepanjang film itu.Bagi peneliti, ucapan yang muncul melalui narasi tersebut dapat dikatakan sebagai salah satu unsur fiktif yang terdapat dalam dokumenter. Hal ini nampak melalui potongan gambar pada menit ke-02 detik ke-20 sampai menit ke-03 detik ke01:

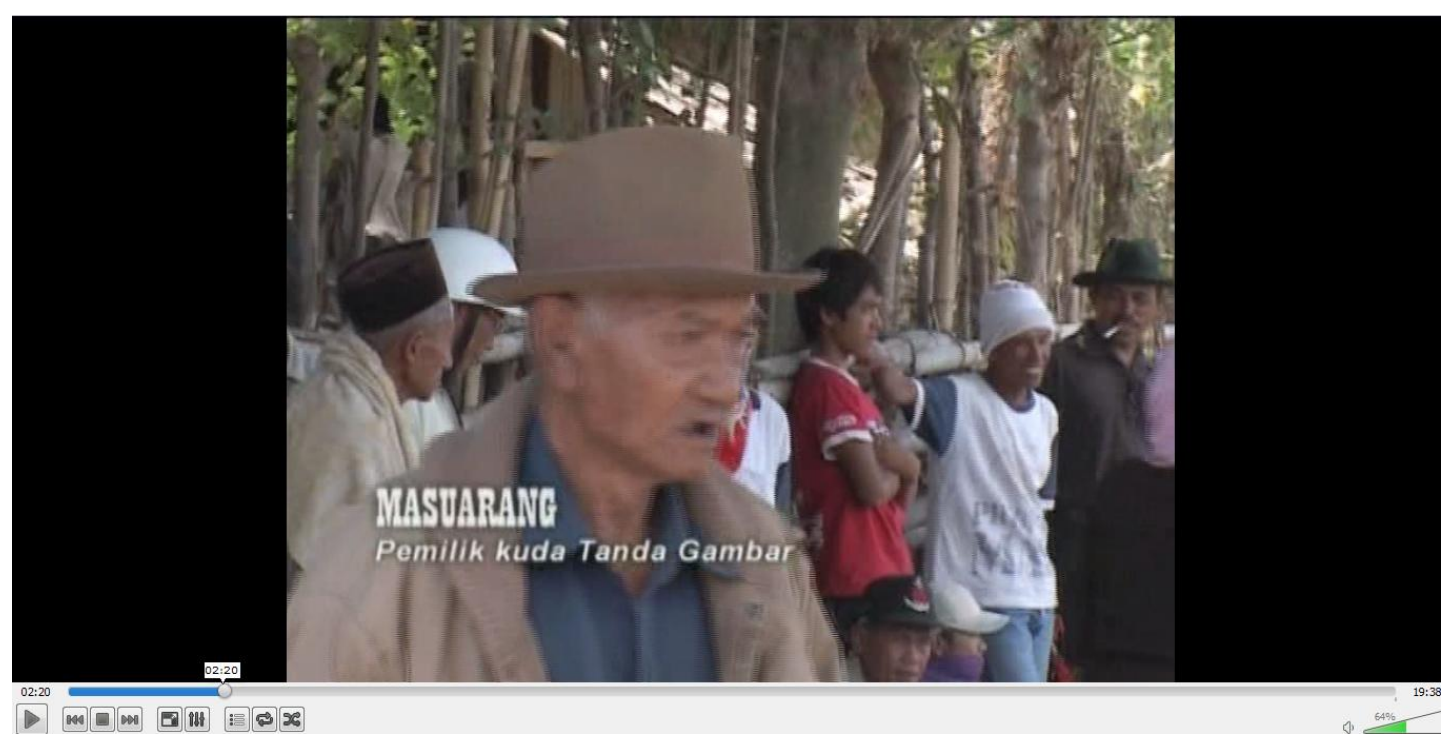

Gb.1. Printscreen durasi 02.20 


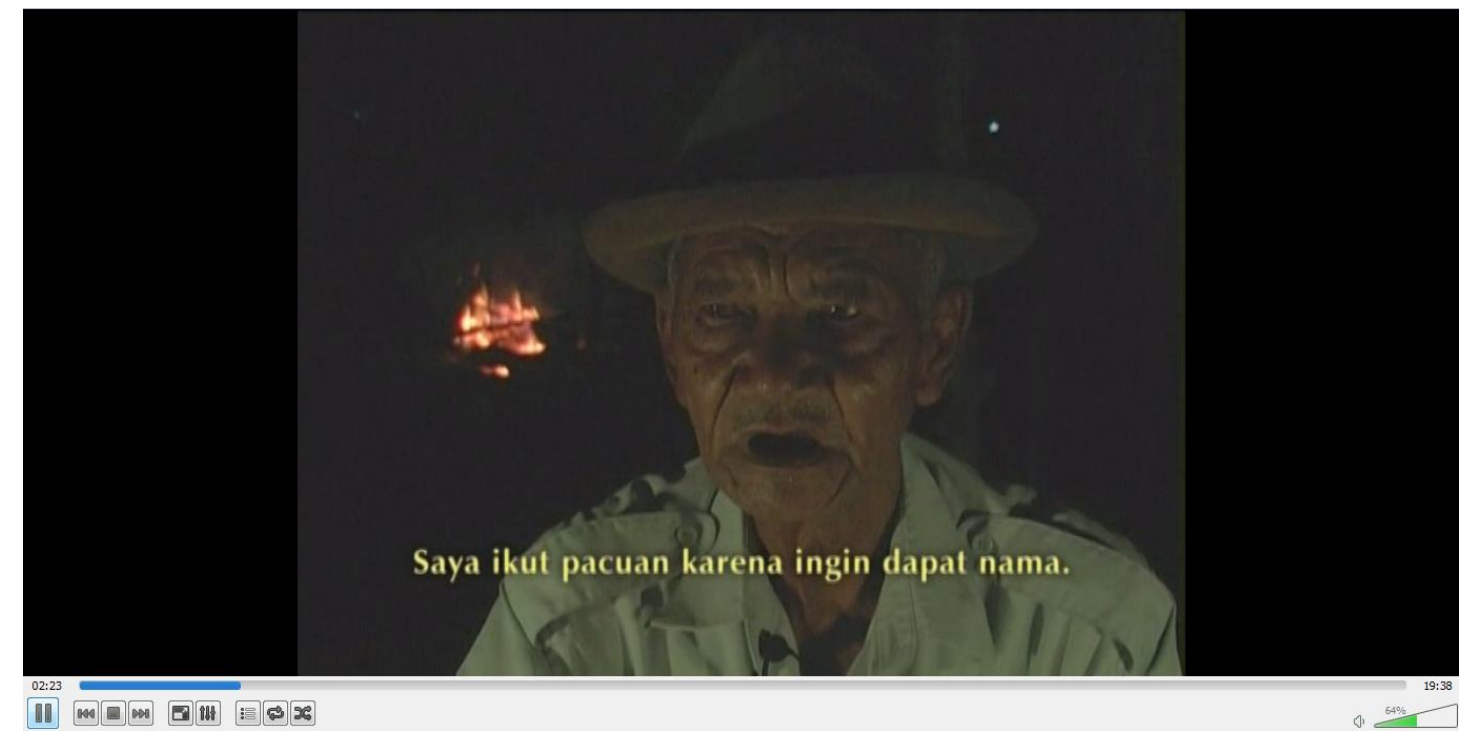

Gb.2. Printscreen durasi 02.23

Pada durasi ini, seseorang bernama Masuarang yang dinamai oleh sineas sebagai pemilik kuda tanda gambar (pada durasi 02.20) menyatakan motif atau keinginan mengikuti pacuan kuda.Motivasi ini masih peneliti anggap wajar apabila dikatakan sebagai sebuah kebenaran karena setiap keinginan yang muncul dari pikiran manusia dilandasi oleh sebuah motif yang meletakan manusia sebagai diri yang selalubergerak untuk memenuhi keinginan. ${ }^{6}$

${ }^{6}$ Alasan manusia berperilaku tertentu (behavior), dan perilaku tersebut adalah bergerak untuk memenuhi kebutuhan (empirisme) akan kesenangan (hedonism) dan menghindari penderitaan (utilitarianisme) (Goldstein dalam Rahmat, 1980: 17). 


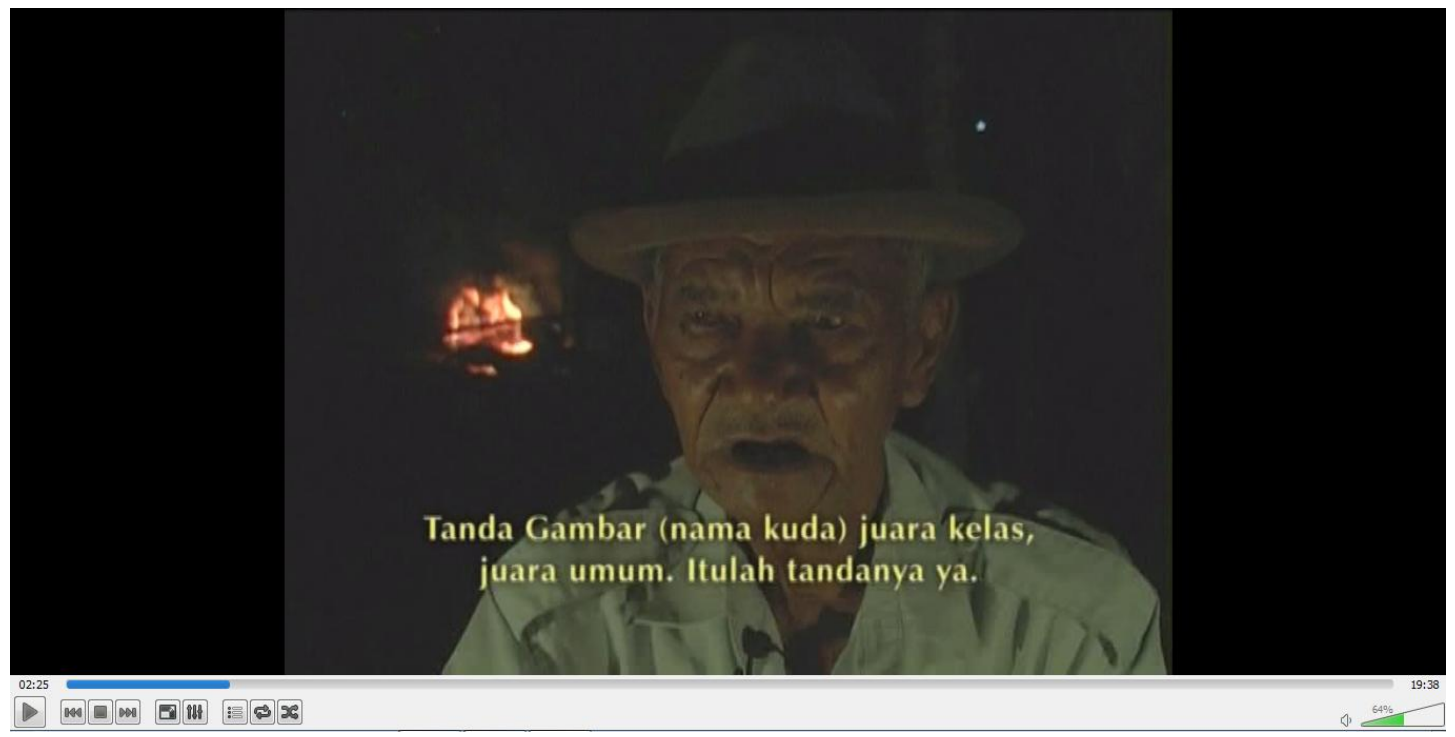

Gb.3. Printscreen durasi 02.25

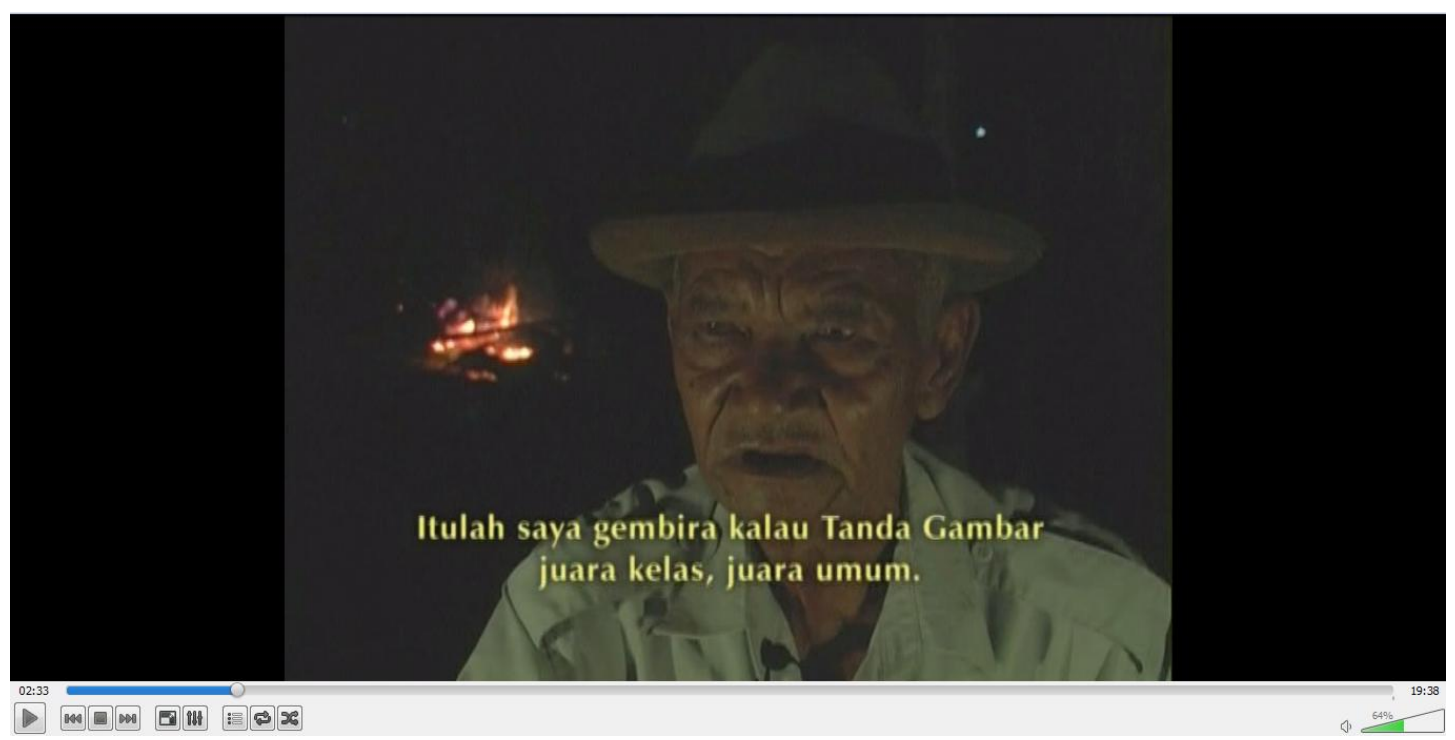

Gb.4. Printscreen durasi 02.33

Pada durasi 02.25 dan 02.33 ini peneliti mulai melihat adanya ketidaksesuaian antara narasi dengan gambar. Pada durasi 02.25, peneliti tidak melihat kuda tanda gambar yang dimaksud saat dinyatakan sebagai pemenang, artinya bentuk kudanya seperti apa, bagaimana proses kuda itu dinyatakan menang, dan tanda seperti apa yang dimaksud pada narasi yang berbunyi "itulah tandanya ya...".Kemudianpada durasi 
02.33, peneliti tidak melihat gambar yang menunjukkan peristiwa kemenangan kuda tanda gambar yang dimaksud, sehingga peneliti berpikir apakah kemenangan itu betul-betul terjadi.

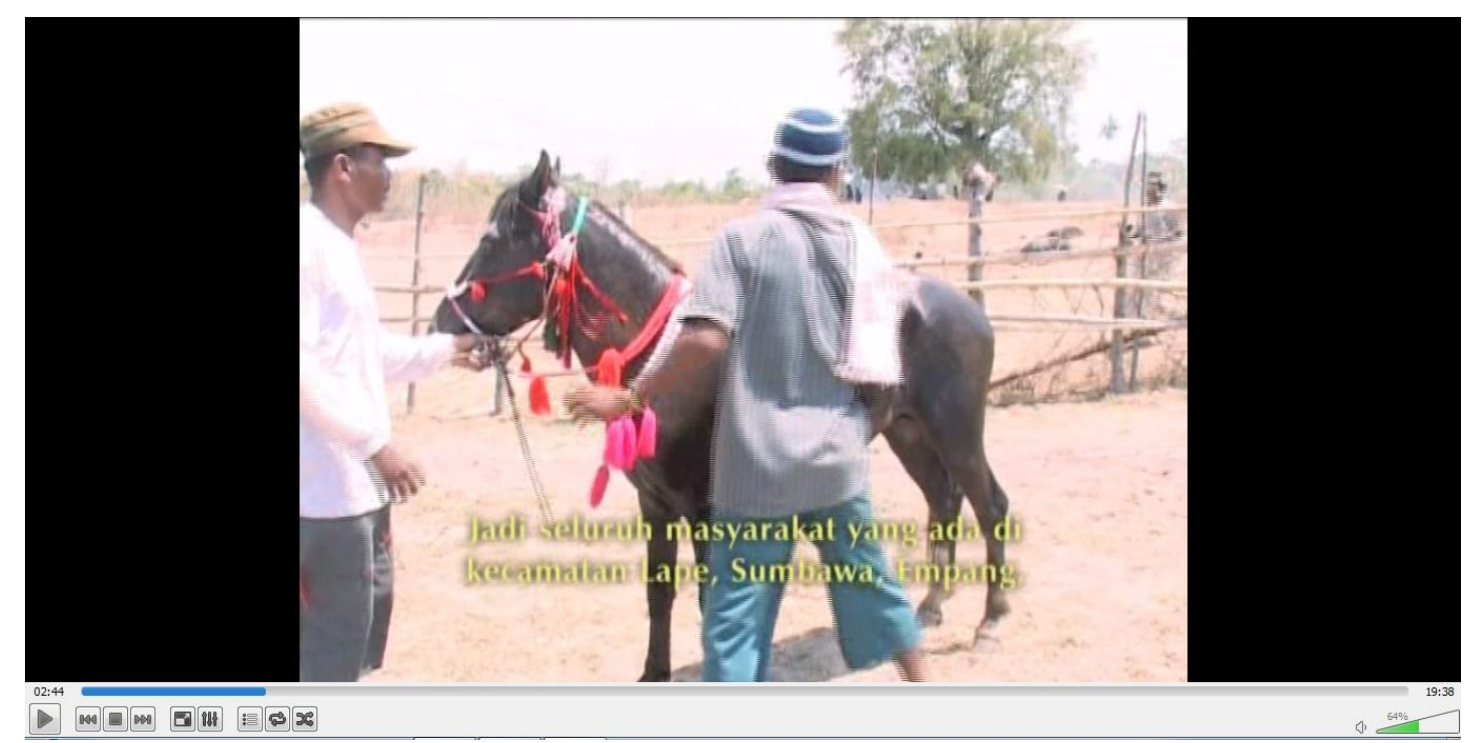

Gb.5. Printscreen durasi 02.44

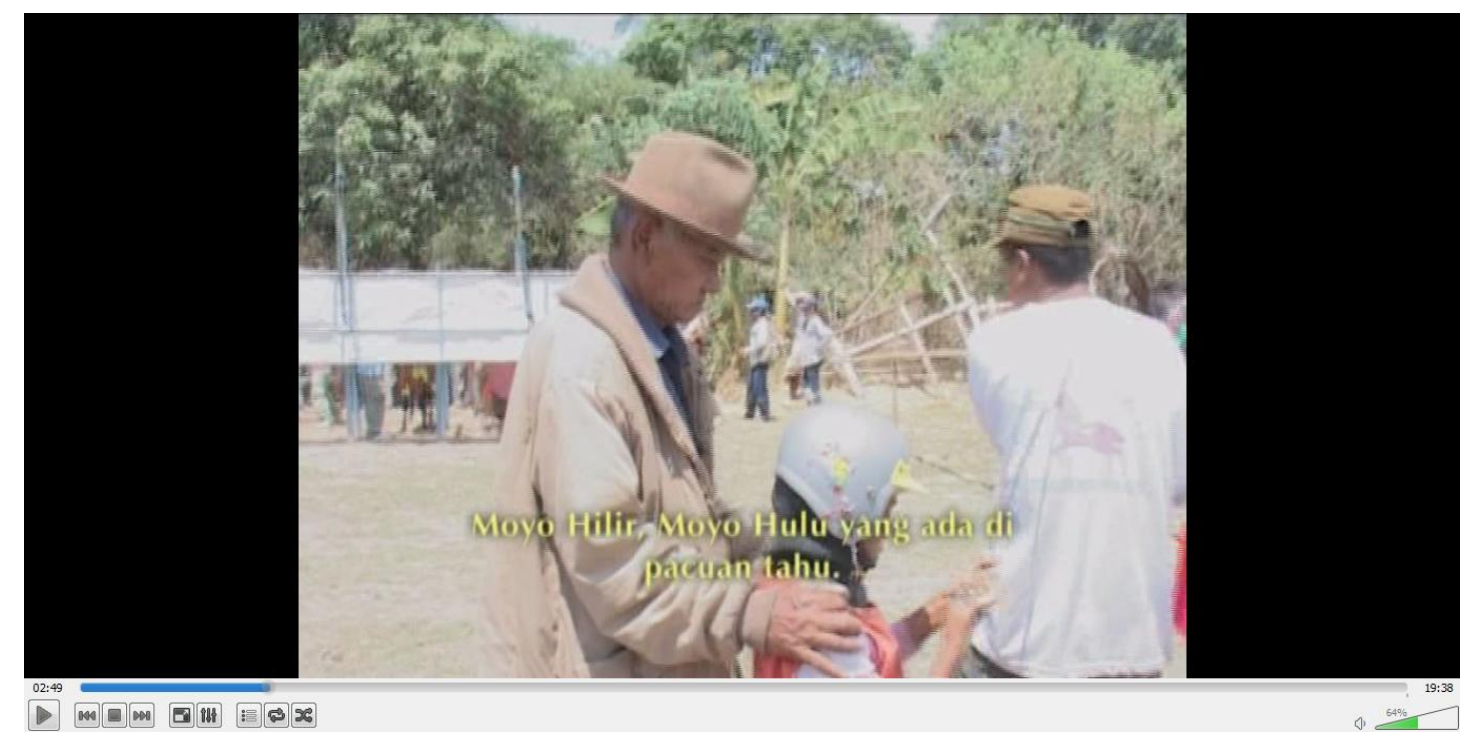

Gb. 6. Printscreen durasi 02.49 


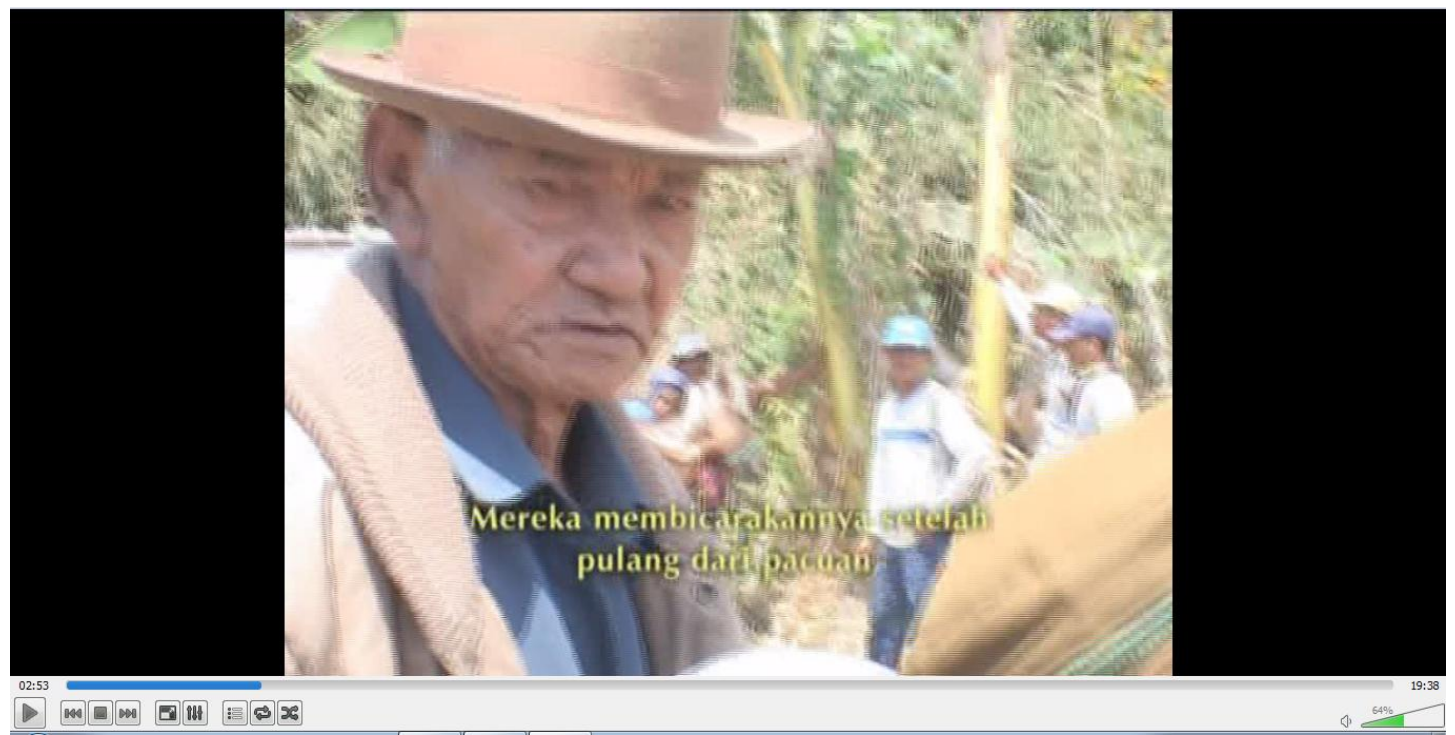

Gb. 7. Printscreen durasi 02.52

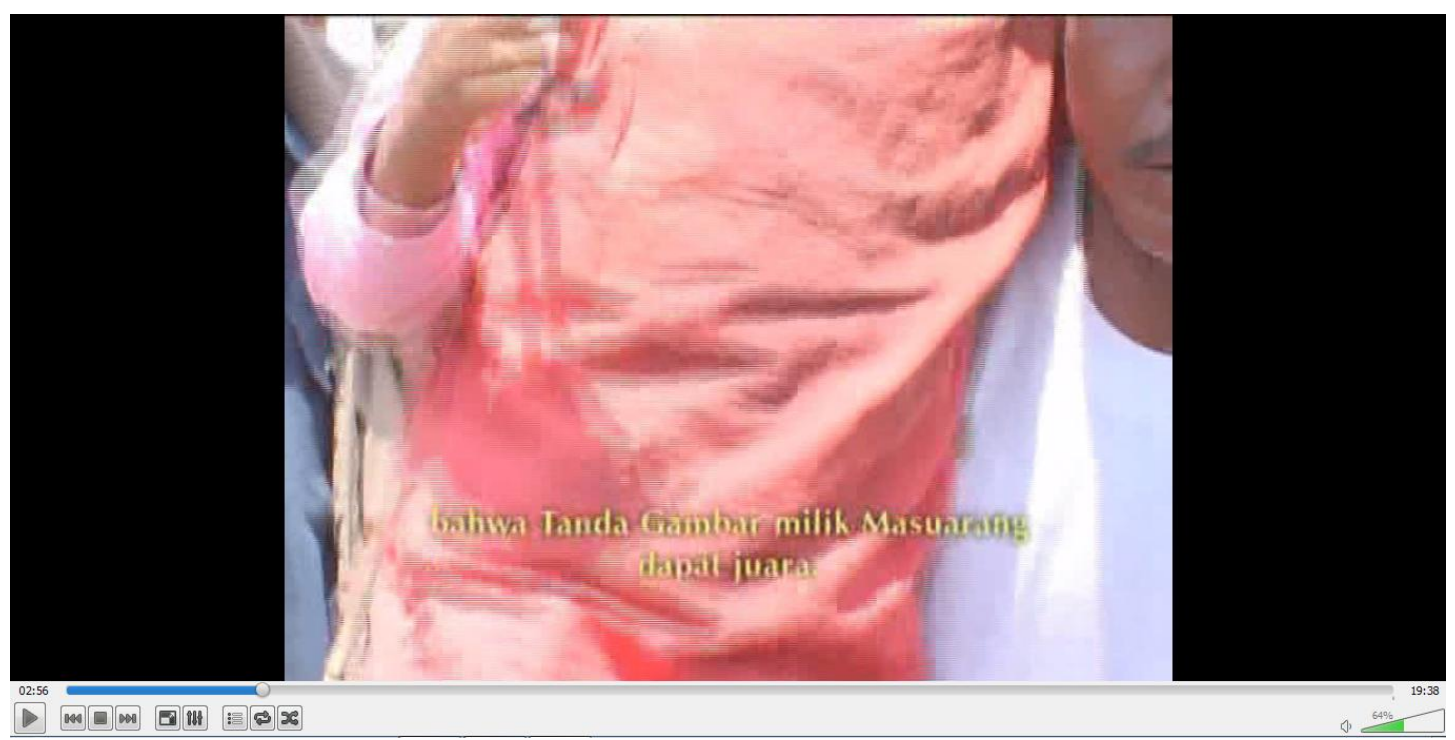

Gb. 8. Printscreen durasi 02.56

Pada durasi 02.44, 02.49, dan 02.52, peneliti kembali menemukan ketidaksinkronan antara narasi dengan gambar. Saat menonton rangkaian adegan pada menit ini, penonton merasa dipaksa untuk membayangkan suasana peristiwa ketika masyarakat di lokasi pacuan kuda, yang dimaksud dalam narasi (Kecamatan Lape, Sumbawa, Empang, Mayo Hilir, Mayo Hulu) mengagumi kehebatan kuda milik Masuarang yang 
memenangkan pacuan kuda. Pada keempat durasi itulah peneliti merasa bahwa letak fiksi dokumenter berada.Ketiadaan gambar untuk membuktikan suatu narasi menjadi unsur pertimbangan bagi peneliti untuk mengatakan bahwa suatu dokumenter memiliki unsur fiksi. Pertimbangan ini merupakan hasil dari proses struktur mental yang dibangun melalui disposisi dalam sudut pandang kognitif. Struktur mental (yang terbangun saat penonton melihat film ini) memiliki peran sebagai mediator yang menggeneralisasikan situasi pada film dengan situasi nyata yang fenomenal. ${ }^{7}$

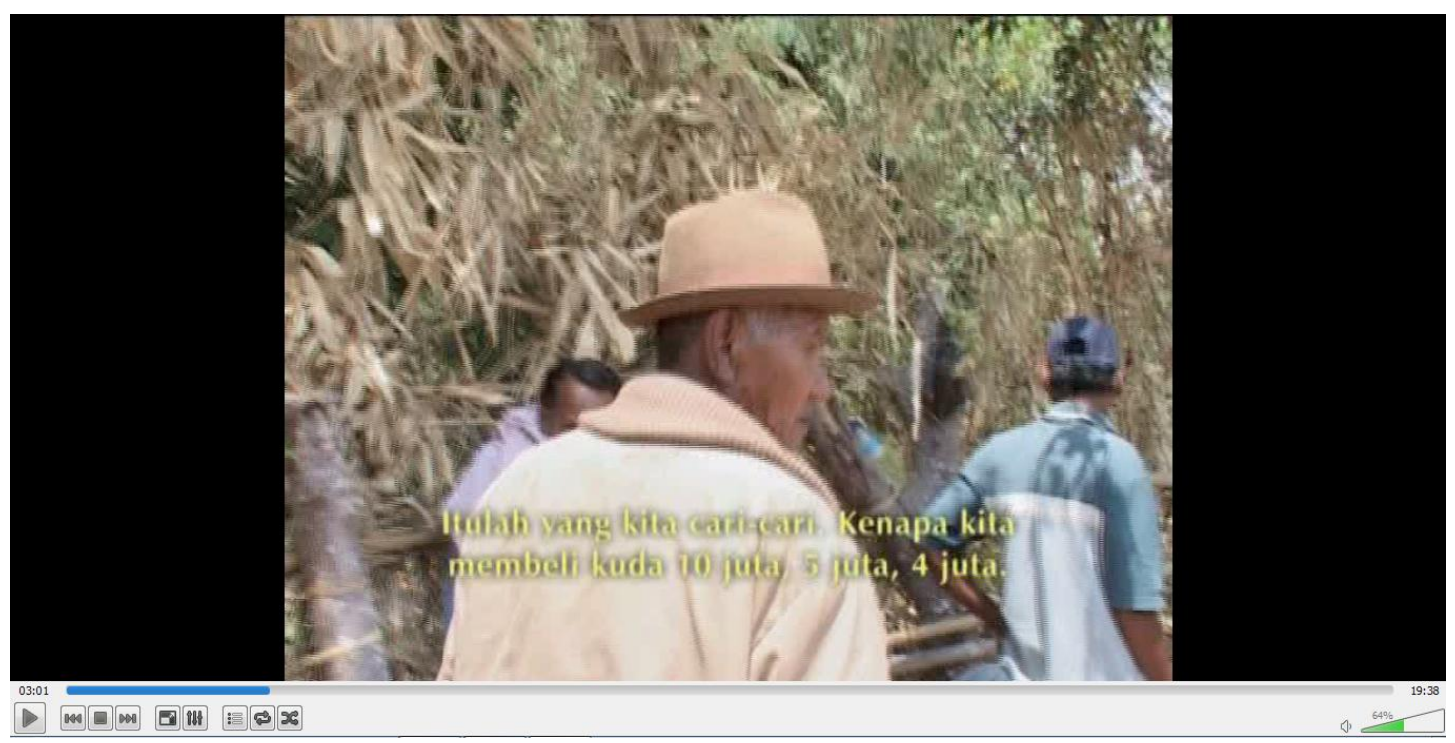

Gb. 9. Printscreen durasi 03.01

Sementara pada durasi 03.01 ini peneliti menganggap bahwa situasi yang digambarkan dalam narasi, merupakan upaya legitimasi tentang kebenaran cerita yang disampaikan pada durasi 02.44, 02.49, dan 02.52.Upaya tersebut peneliti anggap

\footnotetext{
${ }^{7}$ Struktur mental dalam hal ini peneliti asumsikan sebagai bagian yang terdapat pada personal space (ruang pribadi) penonton, dimana pengertian hubungan keduanya mengacu pada salah satutingkat proksemik (berhubungan dengan keadaan diri dalam lingkungan) tertentu (yaitu ruang sekitar setiap individu yang mengikutinya karena ia bergerak di sekitar lingkungan).Fenomenaini digambarkan sebagai semacam batas (sphereataububble)yang mengatur jarak dalam interaksi, sehingga peneliti anggap memerlukan struktur mental untuk menjembatani interaksi tersebut. Kegagalanstruktur mental dalam menjembatani dan mematuhi kode umum di luar personal spacedapatmengarahkesalahpahaman,ketidaknyamanan, atau stress. Banyak dari kitamungkin mengalami masalah saat kontak pertama kali dengan budaya di luar tradisi yang dilazimkan oleh lingkungan sekitar kita (Persson, 2003: 103).
} 
sebagai strategi, entah itu strategi yang dilakukan oleh sineas ataupun subjek untuk menekankan kebenaran dalam film tersebut.

Selain fiksi, unsur fakta sebagai salah satu bagian dari kebenaran dokumenter, peneliti dapatkan pada potongan adegan di durasi menit ke-10 detik ke-41 sampai menit ke-11 detik ke-39.

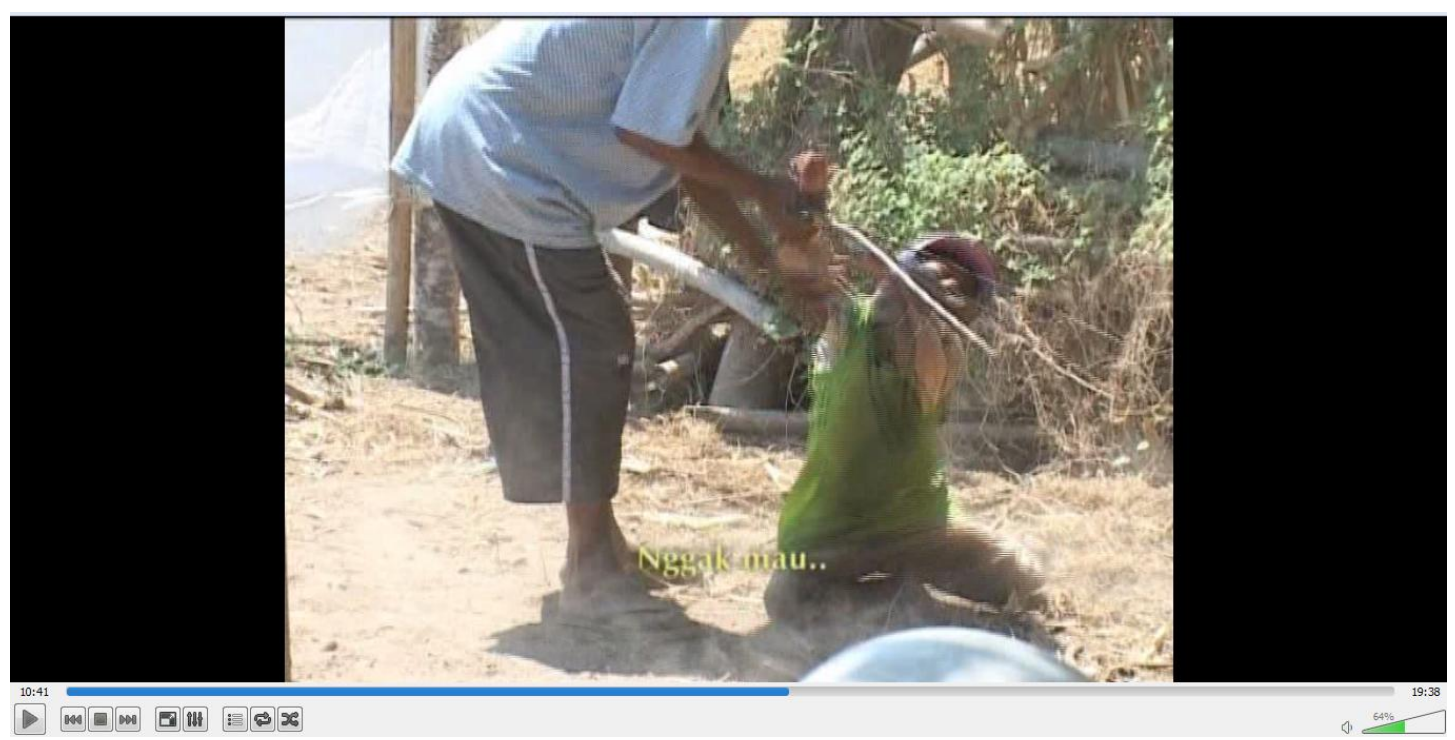

Gb. 10.Printscreen durasi 10.38 .

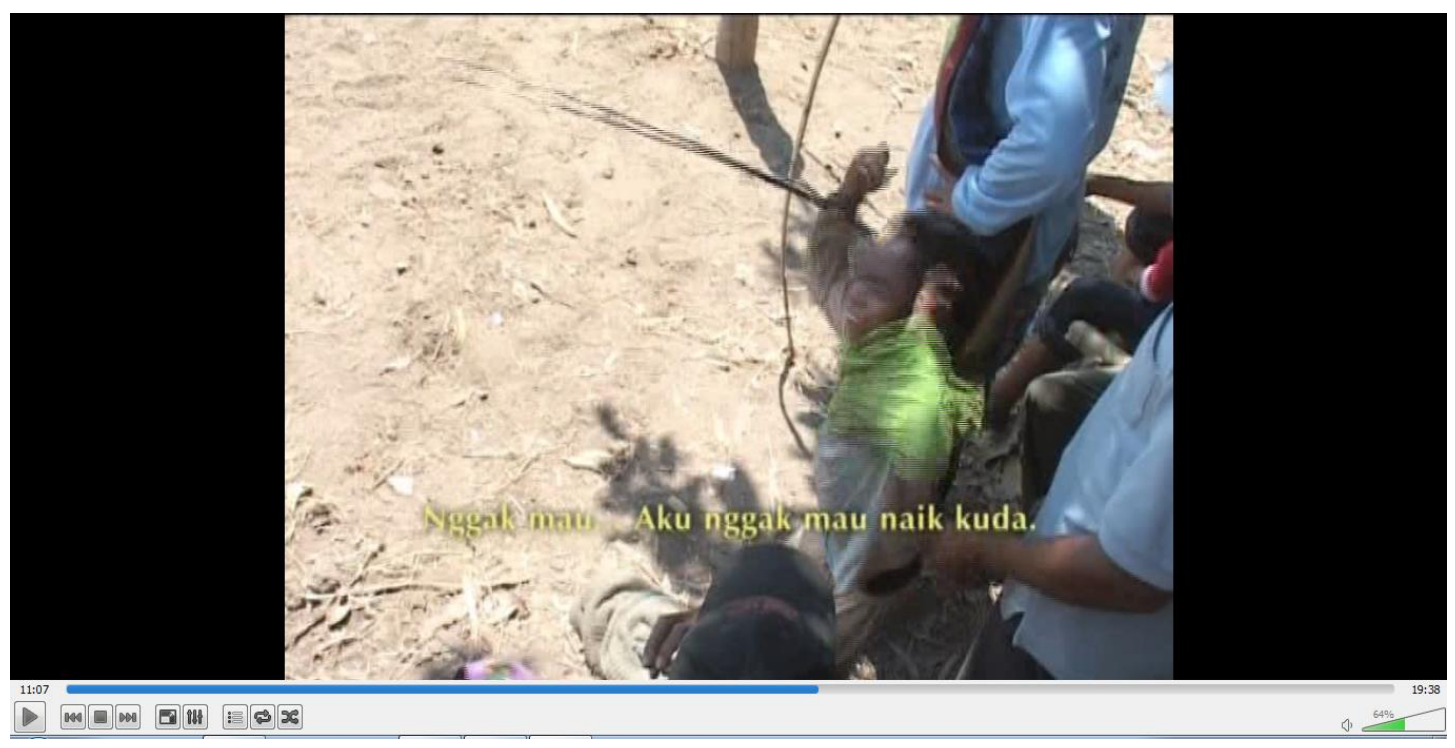

Gb. 11. Printscreen durasi 11.07 
Dalam potongan adegan pada durasi 10.41 dan 11.07 terlihat seorang anak laki-laki yang sedang meronta dengan tangan dipegang oleh laki-laki dewasa.Adegan pada menit ini, mendorong peneliti untuk berpikir hingga menetapkan adanya suatu fakta yang ditunjukkan oleh film melalui kesesuaian antara narasi dengan gambar.Pada durasi 10.41 terlihat adegan anak laki-laki yang meronta sambil berteriak "Nggak mau...".Bagi peneliti, teriakan ini adalah suatu reaksi alamiah yang terjadi jika seseorang merasa tertekan (tersakiti atau terancam).Secara umum, rasa tekanan itu merupakan reaksi yang ditunjukan melalui sikap meronta dan berteriak. ${ }^{8}$

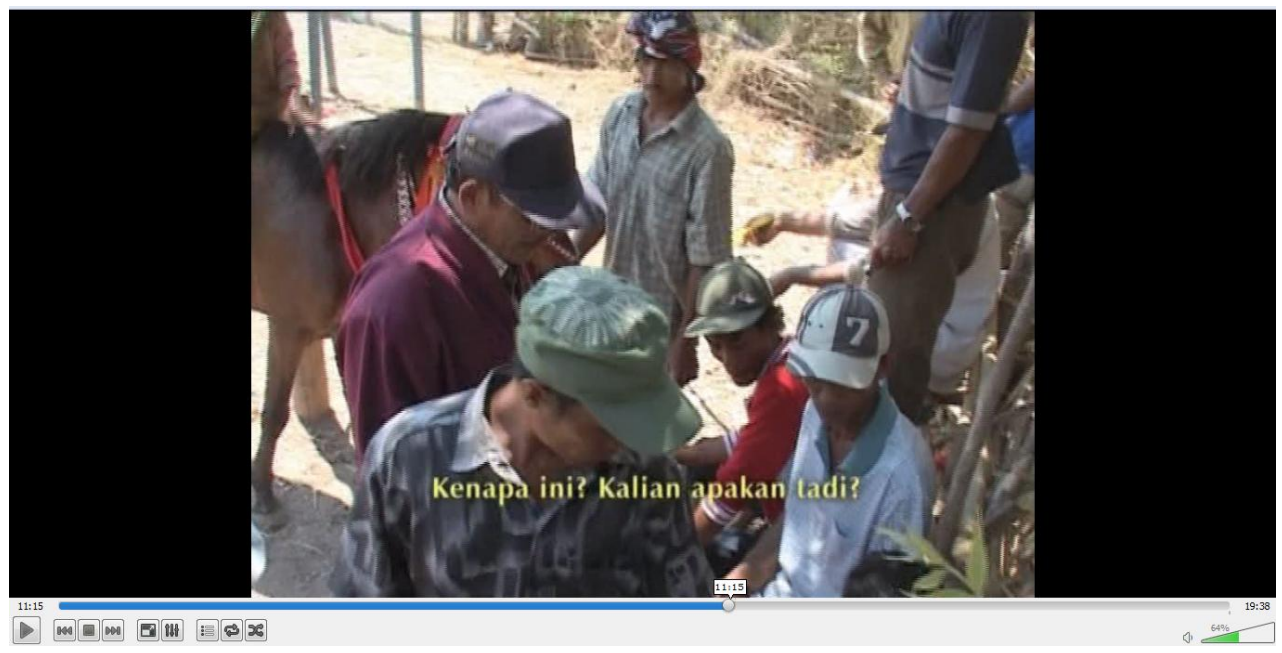

Gb. 12. Printscreen durasi 11.15

\footnotetext{
${ }^{8}$ Peristiwa anak menangis dan pemaksaan merupakan kejadian yang secara umum memiliki dampak psikis bagi siapapun yang menyaksikan.Merujuk pada prinsip psikologi Gestalt tentang isomorphisme, dorongan empati yang muncul akibat mendengar suara tangisan dan melihat perilaku yang invasif, merupakan pengalaman kolektif yang menyeluruh.Artinya pengalaman yang dihadapi bukanlah sebagai bagian dari keseluruhan dalam hubungan fungsional dengan bagian-bagian lainnya.Keseluruhan ada terlebih dahulu baru disusul oleh bagian-bagiannya. Terlepas dari konteks budaya yang berlaku di lokasi dimana film itu dibuat, secara kolektif hasrat manusia akan kebutuhan afeksi (cinta, perhatian, dan kasih sayang) akan merasa terganggu jika ada perilaku yang menghalangi (menciderai). Hal ini dibuktikan dengan tingkah laku memberontak, menangis, dan berteriak ketika seorang anak dipaksa bahkan mungkin dilukai demi untuk melakukan perbuatan tertentu, menyebabkan sesaat orang berpikir bahwa itu menyakitkan (Lehar, 2003: 32).
} 
Dalam potongan adegan pada durasi 11.15, muncul seorang laki-laki dewasa yang menanyakan tentang peristiwa saat si anak laki-laki itu menangis.Kemudian disambung pada durasi 11.20, si anak laki-laki mengatakan bahwa dia baru saja dimarahi oleh seseorang.Si anak laki-laki berbicara dengan sikap membelakangi beberapa orang dan memperlihatkan gesture menangis.Selanjutnya pada adegan durasi 11.25 seorang laki-laki membujuk si anak laki-laki agar mau melakukan pacu kuda.Dalam rangkaian adegan pada durasi 10.41-11.25 ini, kesesuaian antara narasi dengan gambar kembali ditemukan oleh peneliti yang mana rangkaian adegan tersebut menyatakan tentang keberadaan fakta di lokasi pacuan kuda yang melibatkan ketegangan antara anak kecil (joki kuda) dengan beberapa orang dewasa.

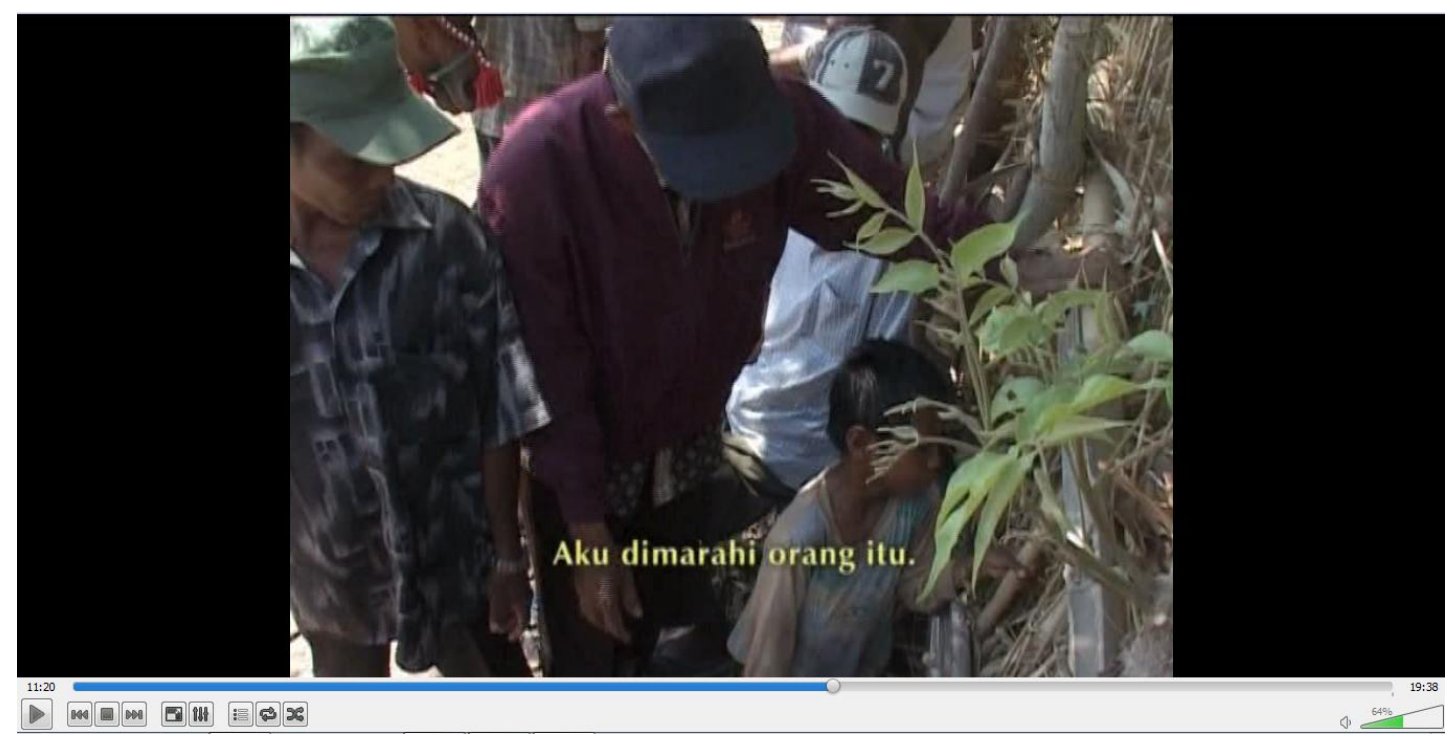

Gb. 13. Printscreen durasi 11.20 


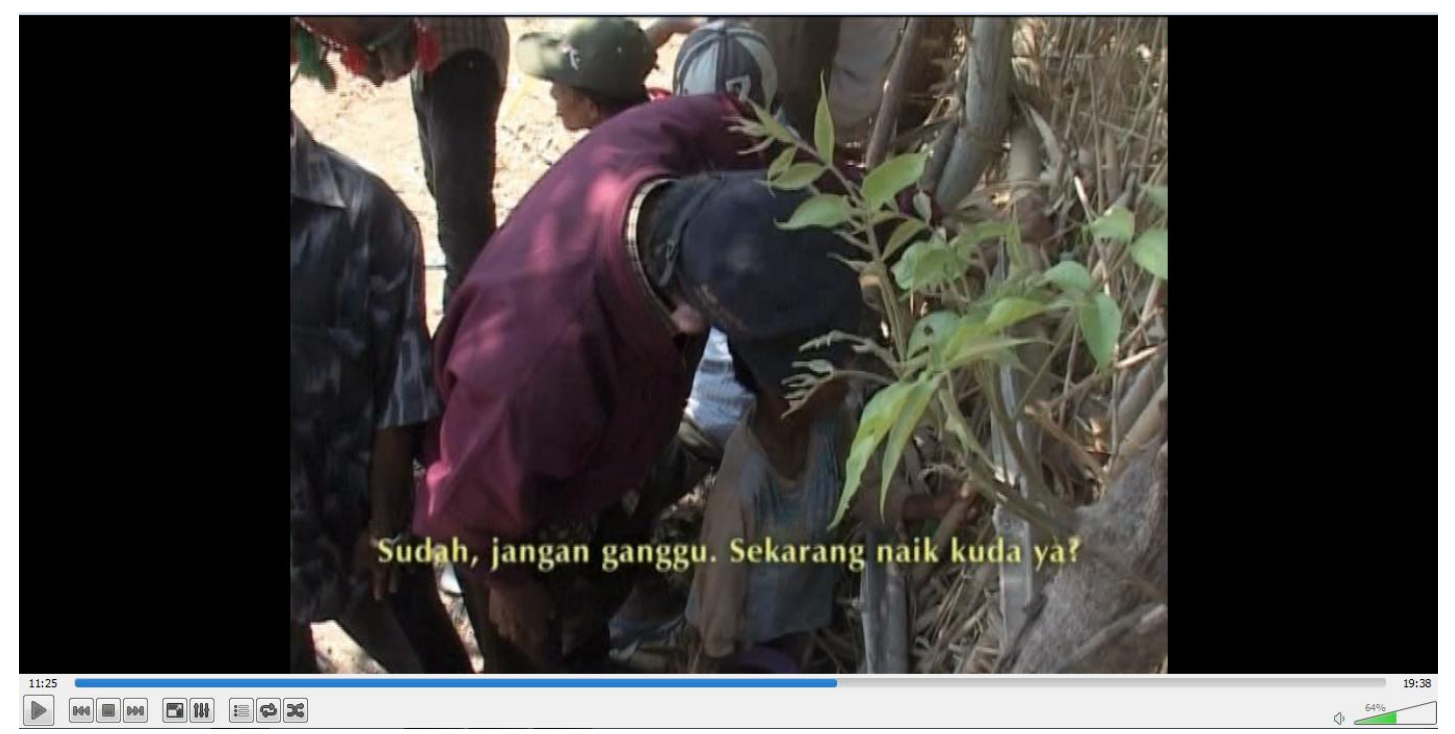

Gb. 14. Printscreen durasi 11.25

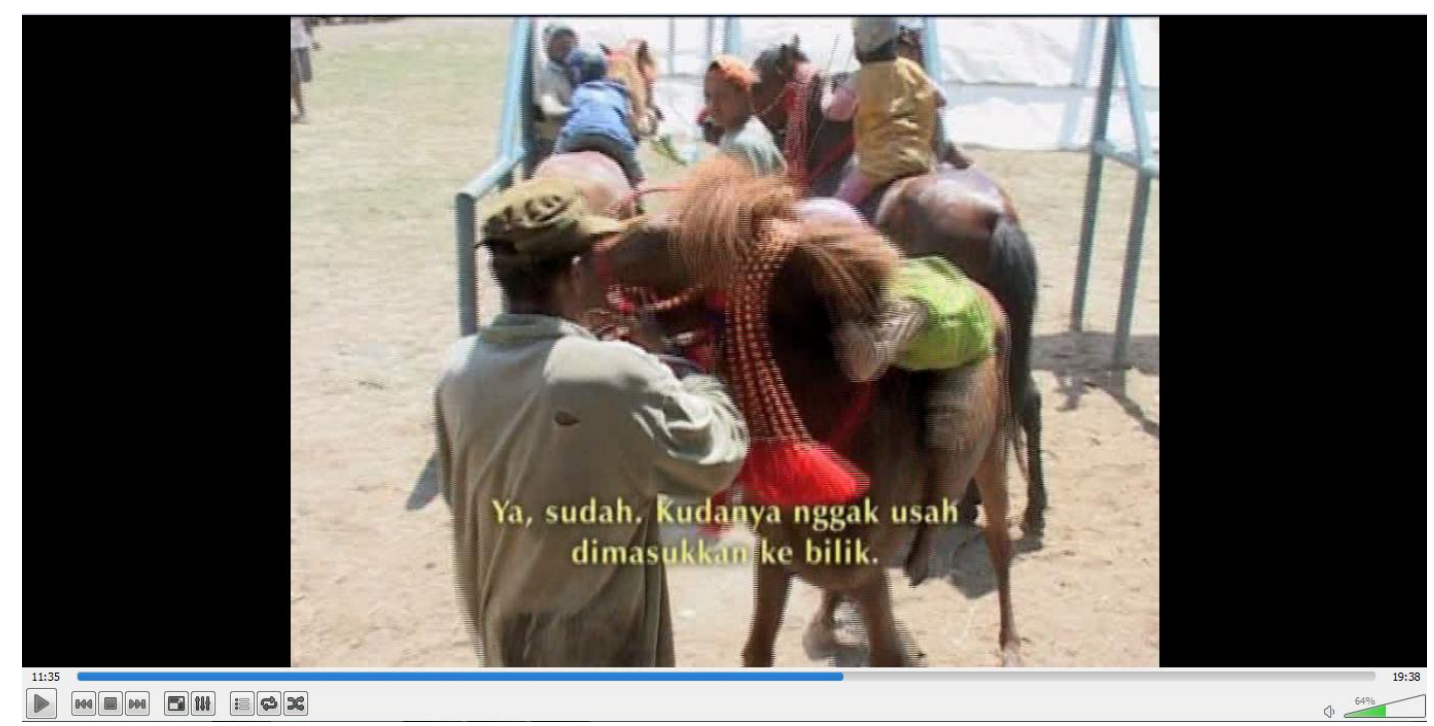

Gb. 15. Printscreen durasi 11.35 


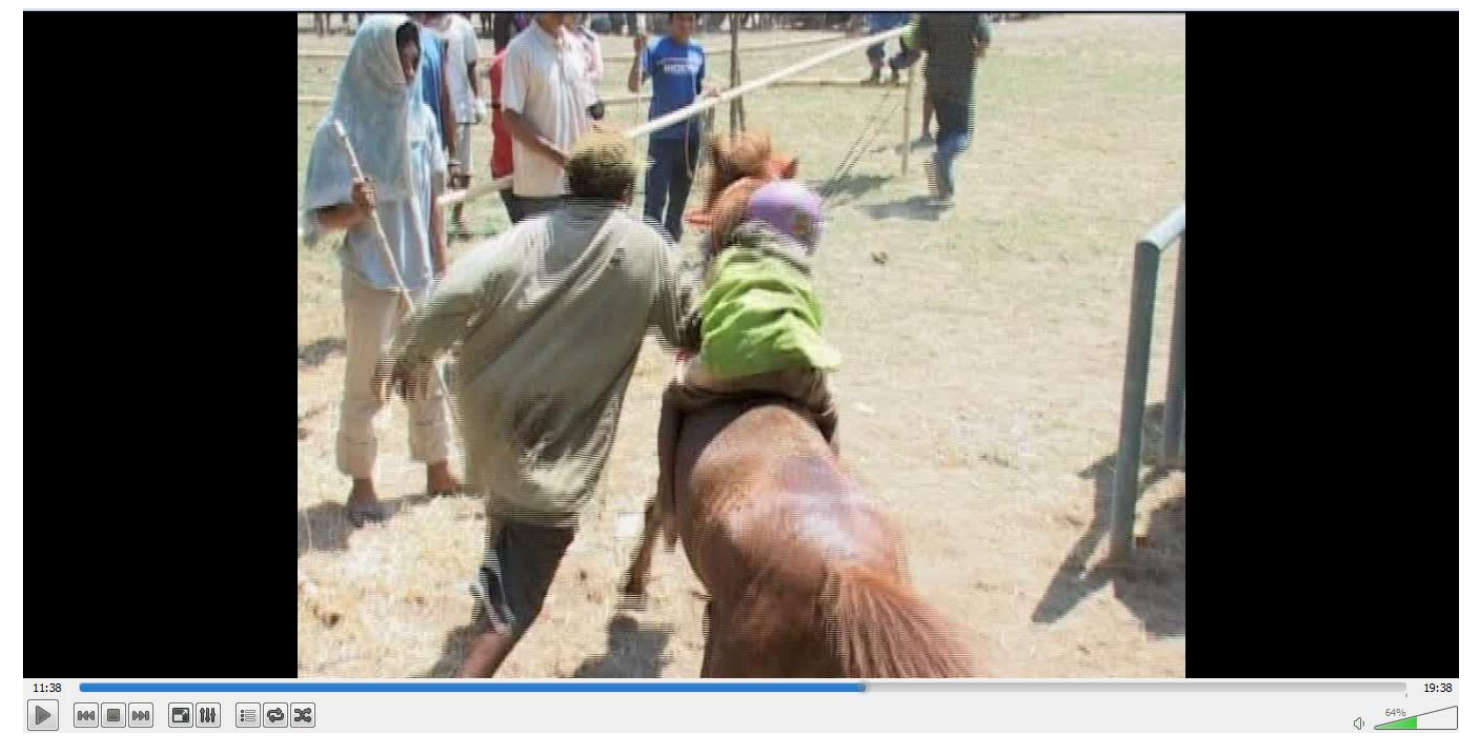

Gb. 16. Printscreen durasi 11.38

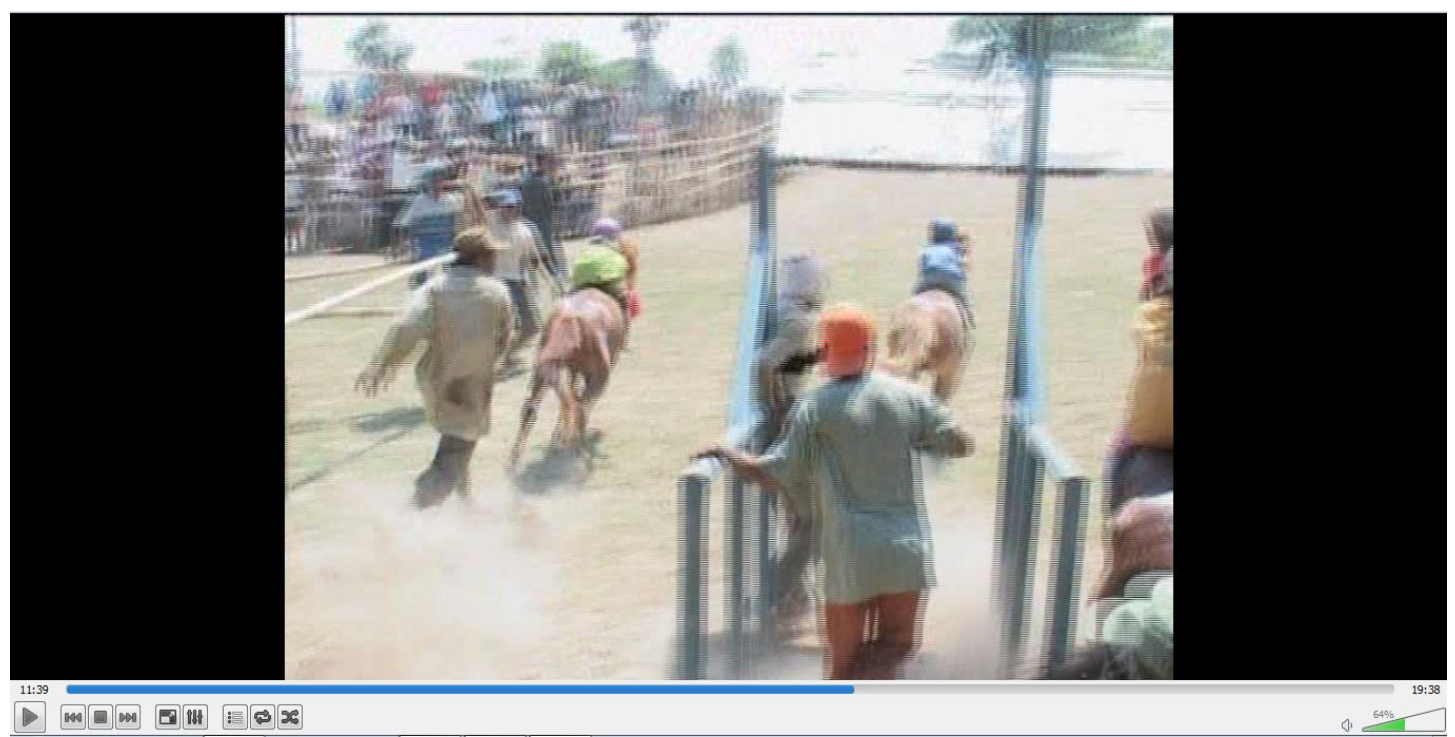

Gb. 17. Printscreen durasi 11.39

Terakhir pada potongan adegan durasi 11.25, 11.35, 11.38, 11.39, terdapat rangkaian proses yang awalnya memperlihatkan seorang laki-laki dewasa membujuk seorang anak laki-laki yang menangis tadi untuk mau menjoki kuda. Kemudian ditunjukkan dalam gambar bahwa anak tersebut bersedia menaiki kuda.Melalui narasi yang 
muncul dalam percakapan pada situasi kejadian, peneliti melihat fakta tentang bagaimana laki-laki dewasa tersebut berusaha agar pacuan kuda berhasil dilaksanakan.Setelah kalimat "Ya sudah, Kudanya nggak usah dimasukkan ke bilik..." pada potongan adegan durasi 11.35, terlihat kegiatan pacuan kuda berlangsung pada potongan adegan durasi 11.38 dan 11.39. Proses yang terjadi dalam rangkaian tersebut menunjukkan bahwa fakta dalam film dokumenter ini nampak melalui hubungan narasi dengan gambar yang berjalan simultan.

\section{KESIMPULAN}

Kesimpulan dari analisis yang sudah peneliti lakukansetelah menonton film dokumenter "Joki Kecil" adalah bahwa secara kognitif, unsur fakta dan fiksi dalam sebuah dokumenter, khususnya dokumenter tipe ekspositori terletak pada hubungan narasi dengan gambar. Dokumenter "Joki Kecil” merupakan salah satu dari sekian banyak dokumenter produksi Eagle Award yang cenderung menggunakangaya ekspositori. ${ }^{9}$ Dalam pengamatan terhadap dokumenter tipe ini, peneliti menganggap bahwa klaim kebenaran yang disajikan sebagai bentuk faksi (fakta dan fiksi) dalam gaya ekspositori, menggunakan kekuatan narasi di hampir sebagian besar durasinya untuk melegitimasi kebenaran dan pembangunan makna. ${ }^{10}$

\section{REFERENSI}

Blumenberg, Richard. M., 1977.Documentary Films and the Problem of "Truth".Journal of the University Film Association, Vol. 29, No. 4.

Eisenstein, Sergei. 1969.Film Form. San Diego: A Harvest Book.

Kuehl, Jerrydan Alan Rosenthal (ed). 1988. Truth Claims-New Challenge for Documentary: The Voice of Documentary. Berkeley: University of California.

\footnotetext{
${ }^{9}$ Tipe dokumenter yang lain dalam Eagle Award dapat dilihat dalam website: eagleawardsdoc.com. Dokumenter eagle award cenderung menggunakan gaya ekspositori dalam karya sineasnya.

${ }^{10}$ Penggunaan narasi terjadi dari menit 02.20-10.41 dan 13.25-15.20 dari total durasi 19.38.peneliti anggap penggunaan narasi memakan lebih dari separuh durasi.
} 
Lehar, Steven. 2003. The World in Your Head: A Gestalt View of the Mechanism of Conscious Experience. London: Lawrence Elbaum Associates Publisher.

Nichols, Bill. 2001. Introduction to Documentary. Bloomington: Indiana University Press.

Persson, Per. 2003. Understanding Cinema:A Psychological Theory of Moving Imagery. Cambridge: Cambridge University Press.

Rakhmat, Djalaludin. 2006. Psikologi Komunikasi. Jakarta: Rosda.

Williams, Linda. 1993. Mirrors without Memories: Truth, History, and the New Documentary. Film Quarterly, Vol. 46, No. 3 (Spring, 1993). 